\title{
ANALISIS DAYA DUKUNG TIANG AKSIAL DENGAN MEMPERTIMBANGKAN POTENSI LIKUIFAKSI
}

\author{
Randy Dewangga Lokananta ${ }^{1}$ dan Alfred Jonathan Susilo ${ }^{2}$ \\ ${ }^{1}$ Program Studi Sarjana Teknik Sipil, Universitas Tarumanagara, Jl. Letjen S. Parman No.1 Jakarta \\ Email: randy_lokananta@yahoo.com \\ ${ }^{2}$ Program Studi Sarjana Teknik Sipil, Universitas Tarumanagara, Jl. Letjen S. Parman No.1 Jakarta \\ Email: alfredsusilo@gmail.com
}

\begin{abstract}
ABSTRAK
Likuifaksi yang terjadi menyebabkan kerugian materiil dan non-materiil yang sangat besar. Kerusakan dapat berdampak pada infrastruktur yang berada di permukaan, seperti bangunan, jalan, bendungan, jembatan, dan sebagainya. Analisis potensi likuifaksi menggunakan metode Tsuchida (1970), "Chinese Criteria", Seed et al (2003), dan Bray \& Sancio (2004). Selain itu digunakan rasio tegangan siklik (CSR) dan rasio hambatan siklik (CRR) untuk analisis potensi likuifaksi. Perencanaan bangunan pondasi sebaiknya memperhitungkan faktor likuifaksi karena dapat mempengaruhi daya dukung tiang. Dengan factor keamanan 2.5, dilakukan analisis dengan mengabaikan friksi pada selimut tiang dan menambahkan beban akibat gesekan selimut negatif. Maka daya dukung yang didapatkan sebesar 395.327 ton per satu tiang. Daya dukung dari hasil analisis lebih besar dari daya dukung yang didapat dari perencana, yaitu sebesar 350 ton.
\end{abstract}

Kata kunci: likuifaksi, daya dukung tiang, N-SPT, rasio tegangan siklik (CSR), rasio hambatan siklik (CRR)

\section{PENDAHULUAN}

Wilayah Indonesia memiliki tanah yang berpotensi terjadi likuifaksi, tetapi hal ini masih kurang diteliti. (USGS, 2013) menyatakan likuifaksi adalah hilangnya kekuatan dari tanah jenuh atau tanah sebagian jenuh yang terjadi karena getaran yang terjadi akibat gempa bumi atau adanya perubahan secara mendadak. Penjelasan mengenai likuifaksi akan lebih lanjut dibahas pada bab selanjutnya. Indonesia adalah negara kepulauan yang dilintasi oleh garis khatulistiwa, dikelilingi oleh gugusan gunung berapi aktif dan berdasarkan letak geografisnya merupakan negara yang berada di jalur gempa dunia. Hal ini menyebabkan tanah yang ada di Indonesia sangat beragam. (Hanafiah, 2007) mengemukakan beberapa jenis tanah yang terdapat di Indonesia, yaitu tanah aluvial, tanah andosol, tanah grumosol, tanah humus, tanah laterit, tanah litosol, tanah latosol, tanah kapur dan tanah pasir.

Berdasarkan data Badan Meteorologi Klimatologi dan Geofisika (BMKG) terdapat 5.578 gempa bumi yang telah terjadi sepanjang tahun 2016 dan 8.693 gempa bumi yang telah terjadi sepanjang tahun 2017. Dari data di tahun 2017, terjadi 19 kali gempa yang sifatnya merusak, 208 kali gempa dengan kekuatan diatas 5 skala richter (SR). Gempa bumi dapat dilihat dari berbagai aspek, yaitu dari penyebabnya, kedalaman, dan kekuatan. Menurut (Sukandurrumidi, 2010) berdasarkan penyebabnya, gempa yang terjadi di Indonesia dapat dikategorikan menjadi 4 jenis, yaitu gempa tektonik, gempa vulkanik, gempa runtuhan dan gempa buatan. Maka dari itu, gempa yang terjadi di Indonesia dapat mengakibatkan struktur dan kekuatan tanah berubah.

Banyaknya bangunan tinggi yang dikerjakan dan fakta bahwa Indonesia berada dalam jalur gempa bumi dunia dapat meningkatkan resiko terjadinya keruntuhan pada bangunan. Hal ini dapat mengakibatkan bencana yang sangat merugikan, baik secara materiil maupun non-materiil, seperti trauma, kerusakan lingkungan dan kesedihan akibat adanya korban jiwa. Seperti yang telah dijelaskan pada awal paragraf, Indonesia memiliki tanah yang beragam. Salah satu jenis tanah yang terdapat di Indonesia adalah tanah pasir (sand). Biasanya pada tanah pasir dapat terjadi likuifaksi.

Menurut Marcuson (1978) likuifaksi adalah perubahan butiran tanah dari keadaan padat (solid) menjadi cairan (liquefied) sebagai akibat dari meningkatnya tegangan pori dan menurunnya tekanan efektif. Hal ini dapat terjadi apabila pori-pori tanah besar dan juga mempunyai saluran drainase yang kurang baik, seperti pada tanah pasir, pasir berlumpur, atau pada kerikil yang mengandung endapan kedap air. Dengan adanya tanah yang mempunyai pori-pori besar dan berisi air, maka terjadi pelunakan tanah yang juga menyebabkan hilangnya kekuatan geser sehingga dapat menyebabkan deformasi geser yang cukup besar atau dapat menyebabkan bangunan yang menumpu pada permukaan terlikuifaksi akan kehilangan daya dukung. 
Maka dari itu, diperlukan untuk menahan beban yang dihasilkan, yaitu dengan menggunakan pondasi. Pondasi adalah bagian dari bangunan yang memiliki fungsi untuk meletakkan struktur dan meneruskan beban struktur ke dalam tanah yang cukup kuat untuk mendukung struktur tersebut (Hardiyatmo, 2002). Dalam menentukan jenis pondasi yang akan digunakan, terdapat beberapa faktor yang mempengaruhi, antara lain kondisi tanah dasar, beban yang pondasi terima, peraturan yang berlaku, kemudahan dalam pelaksanaan, biaya, dan sebagainya. Berdasarkan kedalamannya, pondasi dibagi menjadi pondasi dangkal (shallow foundation) dan pondasi dalam (deep foundation) (Das, 1983). Masing-masing dari pondasi tersebut mempunyai ketahanan beban yang berbeda.

Apabila likuifaksi terjadi, maka akan menimbulkan efek gesekan selimut negatif pada tiang. Briaud dan Tucker (1983) memberikan beberapa kriteria apakah gesekan selimut negatif perlu dipertimbangkan dalam perencanaan. Jika salah satu dari kriteria tersebut terpenuhi, maka gesekan selimut negatif perlu dipertimbangkan. Kriteria tersebut adalah:

1. Penurunan total tanah diperkirakan melebihi $100 \mathrm{~mm}$

2. Setelah dilakukan pemancangan tiang, penurunan tanah melebihi $10 \mathrm{~mm}$

3. Tinggi timbunan yang diletakkan pada permukaan tanah eksisting melebihi $2 \mathrm{~m}$

4. Ketebalan dari lapisan tanah lunak melebihi $10 \mathrm{~m}$

5. Penurunan muka air tanah melebihi $4 \mathrm{~m}$

6. Tiang dengan panjang melebihi $25 \mathrm{~m}$.

\section{METODOLOGI PENELITIAN}

Pada bagian ini akan membahas mengenai pengertian dari berbagai metode yang dipakai dan persamaan-persamaan yang akan digunakan dalam analisis data.

\section{Data penyelidikan tanah}

Hal ini merupakan langkah awal yang perlu dimiliki untuk dapat melakukan penelitian. Karena data yang akan digunakan sebagian besar berdasarkan data penyelidikan tanah. Dari data penyelidikan tanah dilakukan uji secara in situ maupun laboratorium. Biasanya terdapat beberapa data yang dihasilkan melalui data penyelidikan tanah, diantaranya data NSPT, uji Triaxial, Grainsize Distribution, Unconfined, Direct Shear, dan sebagainya sesuai dengan kebutuhan.Pada penelitian ini, digunakan data penyelidikan tanah dari PT. Tarumanegara Bumiyasa dengan proyek yang berada di daerah Depok. Pada proyek ini dilakukan 3 pengujian sampel tanah.

\section{Metode tsuchida}

Merupakan metode untuk mengetahui potensi likuifaksi dengan data grainsize distribution. Dilihat dari diameter butir dan persen butiran yang lolos pada saringan. Apabila sampel terdapat pada bagian dalam kurva, maka berpotensi mengalami likuifaksi. Tetapi, apabila berada di luar maka tidak berpotensi mengalami likuifaksi.

\section{Metode chinese criteria}

Merupakan metode untuk mengetahui potensi likuifaksi dengan data grainsize distribution. Dilihat dari Liquid Limit (LL) dibandingkan dengan persen butiran yang lolos pada saringan. Dapat berpotensi likuifaksi apabila Liquid Limit (LL) kurang dari 35\% dan kadar berat tanah liat dengan partikel lebih dari 5um kurang dari $15 \%$.

\section{Metode seed et al}

Merupakan metode untuk mengetahui potensi likuifaksi dengan perbandingan antara Liquid Limit (LL) dengan Plasticity Index (PI). Apabila Liquid Limit (LL) kurang dari 37\% dan Plasticity Index (PI) kurang dari $12 \%$ maka berpotensi besar mengalami likuifaksi. Apabila Liquid Limit (LL) berada antara dari 37\%-47\% dan Plasticity Index (PI) antara 12\%-20\% maka berpotensi mengalami likuifaksi. Apabila Liquid Limit (LL) melebihi $47 \%$ dan Plasticity Index (PI) melebihi 20\% maka tidak berpotensi besar mengalami likuifaksi.

\section{Metode bray dan sancio}

Merupakan metode untuk mengetahui potensi likuifaksi berdasarkan perbandingan antara water content/ Liquid Limit $\left(\mathrm{w}_{\mathrm{c}} / \mathrm{LL}\right)$ dengan Plasticity Index (PI). Metode Bray dan Sancio (2004) menyatakan bahwa tanah yang rentan terhadap likuifaksi adalah jika perbandingan antara water content dengan liquid limit lebih besar sama dengan 0.85 $\left(\mathrm{w}_{\mathrm{c}} / \mathrm{LL} \geq 0.85\right)$ dan plasaticity index $(\mathrm{PI})$ lebih kecil sama dengan $12(\mathrm{PI} \leq 12)$. Sedangkan untuk tanah yang mempunyai perbandingan antara water content dengan liquid limit lebih besar sama dengan $0.8\left(\mathrm{w}_{\mathrm{c}} / \mathrm{LL} \geq 0.8\right)$ dan plasaticity index (PI) lebih besar dari 12 dan lebih kecil sama dengan $20(12 \leq \mathrm{PI} \leq 20)$ berpotensi mengalami likuifaksi, harus dilakukan uji laboratorium untuk mengetahui kerentanan terhadap likuifaksi. Sedangkan untuk tanah dengan PI > 20 dianggap terlalu plastis (clayey) untuk mengalami likuifaksi. 


\section{Metode rasio tegangan siklik (CSR) dan rasio hambatan siklik (CRR)}

Metode ini juga digunakan untuk mengetahui potensi likuifaksi. Berikut adalah CSR dan CRR yang digunakan dengan persamaan:

$$
C S R=0.65\left(\frac{a_{\max }}{g}\right)\left(\frac{\sigma_{v o}}{\sigma_{v o}^{\prime}}\right)
$$

dengan $0.65=$ asumsi sebesar $65 \%$ tegangan geser seragam, $\mathrm{a}_{\max } / \mathrm{g}=$ percepatan gempa maksimum, $\sigma_{\mathrm{vo}}=$ tegangan beban vertikal, $\sigma^{\prime}{ }_{v o}=$ tegangan beban vertikal efektif.

$$
C R R=\left(\frac{\tau_{h}}{\sigma_{v}{ }^{\prime}}\right) \sigma_{v}{ }^{\prime}
$$

dengan $\tau_{\mathrm{h}}=$ tegangan geser siklik, $\sigma^{\prime}{ }_{\mathrm{v}}=$ tegangan beban vertikal efektif.

\section{Daya dukung tiang bor}

Dilakukan analisis daya dukung ujung tiang dan selimut tiang. Analisis dilakukan pada tanah kohesif maupun tanah non-kohesif. Setelah itu diperhitungkan daya dukung tiang total yang dapat ditopang.

\section{Daya dukung ujung tiang bor}

Persamaan berikut merupakan rumus untuk mendapatkan daya dukung ujung tiang.

$$
Q_{p}=q_{p} . A
$$

dengan $\mathrm{Q}_{\mathrm{p}}=$ daya dukung ujung tiang (ton), $\mathrm{q}_{\mathrm{p}}=$ tahanan ujung per satuan luas (ton $/ \mathrm{m}^{2}$ ), $\mathrm{A}=$ luas penampang tiang $\left(\mathrm{m}^{2}\right)$.

O’Neill dan Reese (1999) mengemukakan persamaan berikut merupakan rumus untuk mendapatkan tahanan ujung dengan tanah kosif ketika $\mathrm{s}_{\mathrm{u}} \geq .10$ ton $/ \mathrm{m}^{2}$.

$$
q_{\max }=9 . s_{u}
$$

Dengan $\mathrm{s}_{\mathrm{u}}=$ kuat geser tanah.

Selain persamaan kohesif, O'Neill dan Reese (1999) mengemukakan pula persamaan non-kohesif dengan panjang tiang lebih dari 10 meter yang akan dipaparkan sebagai berikut.

$$
q_{b}=\left(\frac{L}{10}\right) 5.75 N_{S P T} \leq\left(\frac{L}{10}\right) 2.9 M P a
$$

\section{Daya dukung selimut tiang bor}

Berikut adalah persamaan tiang pada tanah berlapis

$$
Q_{S}=\sum_{i=1}^{n} f_{s i} I_{i} p
$$

dengan $\mathrm{Q}_{\mathrm{s}}=$ daya dukung selimut tiang (ton), $\mathrm{f}_{\mathrm{si}}=$ gsekan selimut tiang per satuan luas pada segmen ke-I (ton $\left./ \mathrm{m}^{2}\right), \mathrm{I}_{\mathrm{i}}$ = panjang segmen tiang ke-I $(\mathrm{m}), \mathrm{p}=$ keliling penampang tiang $(\mathrm{m})$

Reese dan Wright (1977) memberikan persamaan untuk mendapat gesekan selimut pada tanah kohesif. Berikut adalah persamaan tersebut.

$$
f_{s}=\alpha \cdot c_{u}
$$

dengan $\mathrm{f}_{\mathrm{s}}=$ gesekan selimut, $\alpha=$ factor adhesi $(0.55), \mathrm{c}_{\mathrm{u}}=$ kuat geser $\left(\operatorname{ton} / \mathrm{m}^{2}\right)$

Reese dan Wright (1977) memberikan pula analisis untuk mendapatkan gesekan selimut untuk tanah kohesif, yaitu dengan korelasi nilai $\mathrm{N}_{\text {SPT }}$ yang ada pada Gambar 1. 


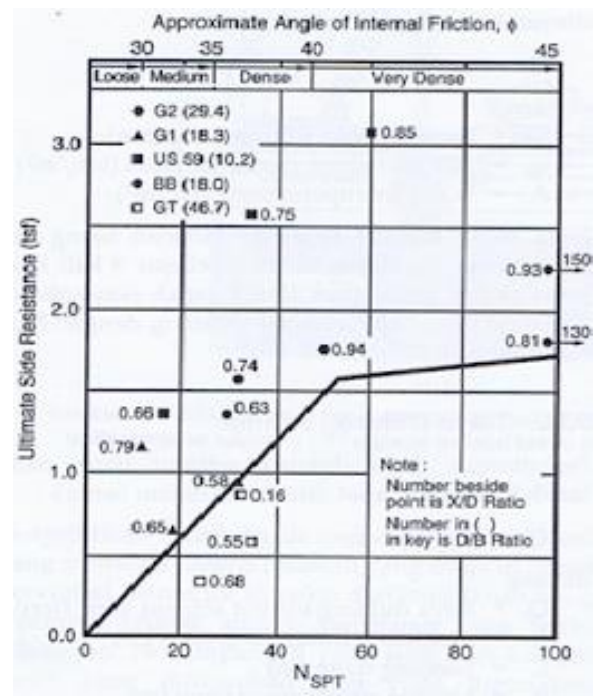

Gambar 1. Hubungan Tahanan Selimut terhadap $\mathrm{N}_{\mathrm{SPT}}$ (Reese dan Wright, 1977)

\section{Gesekan selimut negatif}

Untuk tiang dengan selimut tiang lempung menggunakan persamaan:

$$
f_{n}=K^{\prime} \cdot \sigma_{o}^{\prime} \cdot \tan \delta^{\prime}
$$

dengan $\mathrm{K}^{\prime}=$ koefisien tekanan tanah $=\mathrm{K}_{0}=1-\sin \Phi^{\prime}, \sigma^{\prime}{ }_{\mathrm{o}}=$ tegangan vertikal efektif, $\delta^{\prime}=$ sudut friksi antara tanah dengan tiang $\approx 0.5-0.7 \Phi^{\prime}$

Maka, total penurunan gesekan selimut negatif pada tiang adalah:

$$
Q_{n}=\frac{p \cdot K^{\prime} \cdot \gamma_{f}^{\prime} \cdot H^{2} f \cdot \tan \delta^{\prime}}{2}
$$

dengan dengan $\mathrm{p}=\pi \mathrm{d}, \mathrm{K}^{\prime}=$ koefisien tekanan tanah $=\mathrm{K}_{0}=1-\sin \Phi^{\prime}, \mathrm{\gamma}_{\mathrm{f}}=$ berat jenis tanah efektif, $\mathrm{H}_{\mathrm{f}}^{2}=\mathrm{kedalaman}$ tiang, $\delta^{\prime}=$ sudut friksi antara tanah dengan tiang $\approx 0.5-0.7 \Phi^{\prime}$

\section{ANALISIS DATA}

Pada bagian ini akan dipaparkan mengenai berbagai analisis data sesuai dengan persamaan yang telah dipaparkan pada bagian 2 .

\section{Potensi likuifaksi}

Analisis digunakan 3 sampel titik pengujian, yaitu Deep Boring 1 (DB1), Deep Boring 2 (DB2) dan Deep Boring 3 (DB3) yang masing-masing akan diuji dengan 4 metode. Untuk penjabaran, akan diberikan Deep Boring 3.

\section{Metode tsuchida}

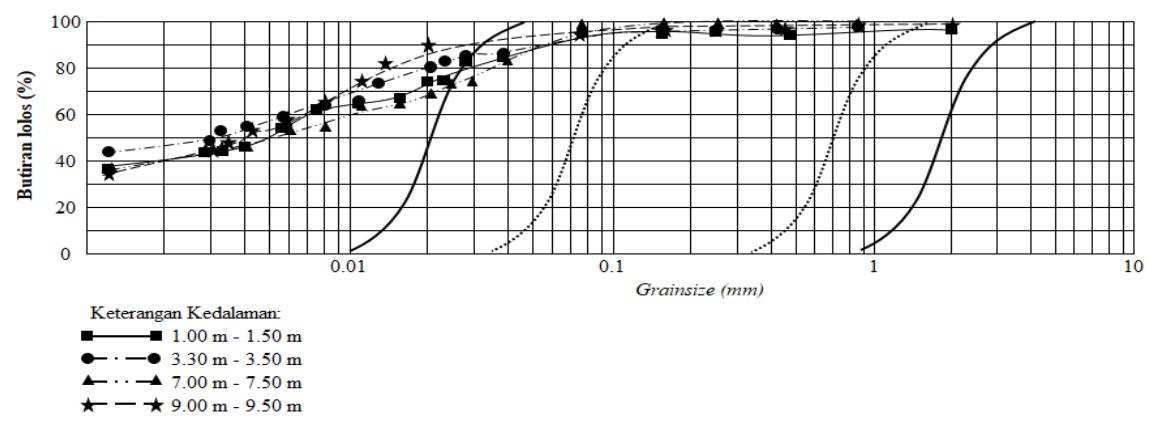

Gambar 2. Hasil DB3 dengan metode Tsuchida 


\section{Metode Chinese criteria}

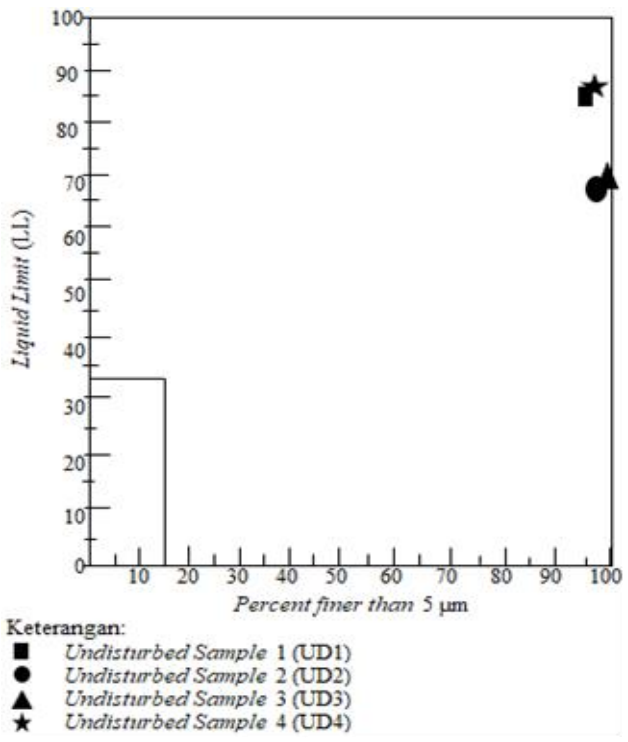

Gambar 3. Hasil DB3 dengan metode Chinese Criteria

\section{Metode bray dan sancio}

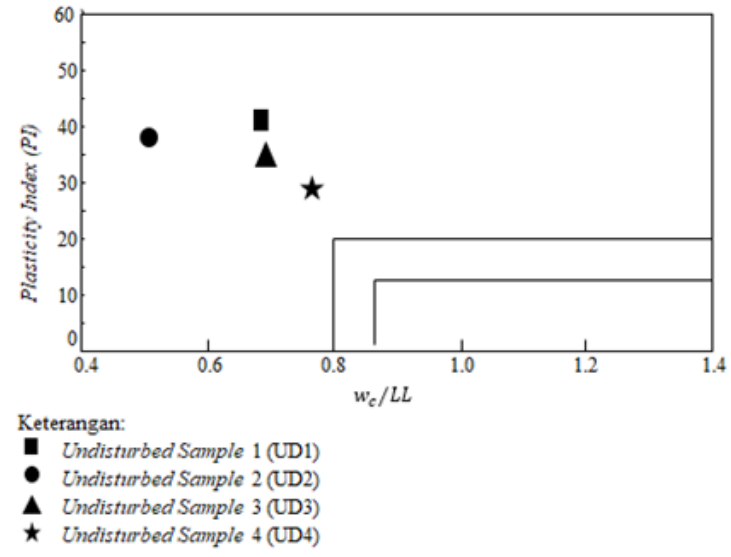

Gambar 4. Hasil DB3 dengan metode Bray \& Sancio

\section{Metode seed et al}

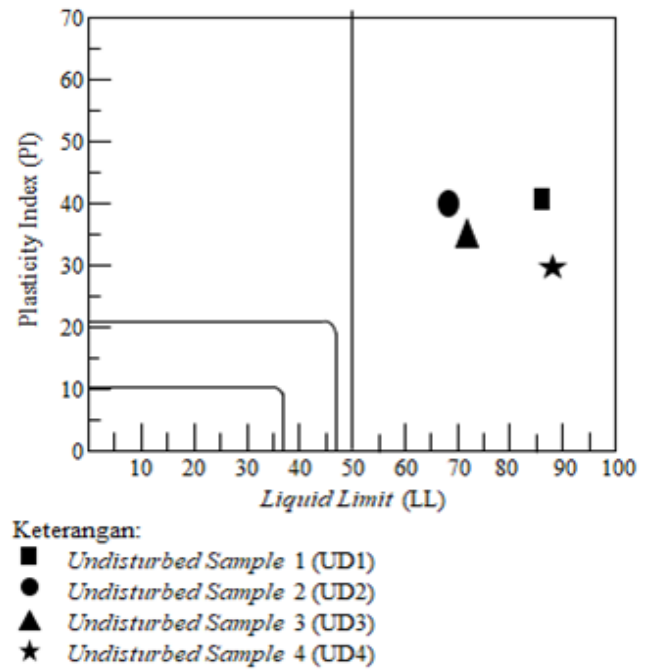

Gambar 5. Hasil DB3 dengan metode Seed et al 


\section{Rasio tengangan siklik (CSR) dan rasio hambatan siklik (CRR)}

Analisis dengan menggunakan metode ini dilakukan terhadap semua sampel tanah yang didapat. Berikut adalah rasio tegangan siklik (CSR) untuk DB3.

Tabel 1. Analisis rasio tegangan siklik (CSR) Deep Boring 3 (DB3)

\begin{tabular}{|c|c|c|c|c|}
\hline Kedalaman & $\begin{array}{c}\text { Total Stress } \\
\sigma_{\mathrm{v}}\left(\text { ton } / \mathrm{m}^{2}\right)\end{array}$ & $\mathrm{a}_{\max } / \mathrm{g}$ & $\mathrm{r}_{\mathrm{d}}$ & $\begin{array}{c}\mathrm{T}_{\mathrm{av}} \\
\left(\text { ton } / \mathrm{m}^{2}\right)\end{array}$ \\
\hline 2 & 3.26 & 0.3 & 0.99 & 0.6293 \\
\hline 4 & 6.68 & 0.3 & 0.97 & 1.2635 \\
\hline 6 & 10.26 & 0.3 & 0.96 & 1.9207 \\
\hline 8 & 13.74 & 0.3 & 0.94 & 2.5185 \\
\hline 10 & 17.01 & 0.3 & 0.91 & 3.0184 \\
\hline
\end{tabular}

Pada Tabel 3. akan dipaparkan mengenai rasio hambatan siklik (CRR) berdasarkan DB3

Tabel 2. Analisis rasio hambatan siklik (CRR) Deep Boring 3 (DB3)

\begin{tabular}{|c|c|c|c|c|c|c|}
\hline Kedalaman & $\begin{array}{c}\text { Vertical eff. Stress } \\
\left.\sigma_{\mathrm{v}^{\prime}}{ }^{(\text {ton }} / \mathrm{m}^{2}\right)\end{array}$ & $\begin{array}{c}\mathrm{C}_{\mathrm{N}} \\
\left(\text { ton } / \mathrm{m}^{2}\right)\end{array}$ & $\begin{array}{c}\text { N lapangan } \\
(\text { pukulan/m) }\end{array}$ & $\mathrm{N}^{\prime}$ koreksi & $\mathrm{Th}_{\mathrm{h}} / \sigma_{\mathrm{v}}{ }^{\prime}$ & $\begin{array}{c}\mathrm{T}_{\mathrm{h}} \\
\left(\text { ton } / \mathrm{m}^{2}\right)\end{array}$ \\
\hline 2 & 3.26 & 1.7514 & 3 & 6 & 0.061 & 0.1989 \\
\hline 4 & 5.68 & 1.3269 & 2 & 3 & 0.045 & 0.2556 \\
\hline 6 & 7.26 & 1.1736 & 2 & 3 & 0.045 & 0.3267 \\
\hline 8 & 8.74 & 1.0697 & 4 & 5 & 0.057 & 0.4982 \\
\hline 10 & 10.01 & 0.9995 & 7 & 7 & 0.07 & 0.7007 \\
\hline
\end{tabular}

\section{Analisis daya dukung tiang}

Dalam melakukan analisis daya dukung tiang, digunakan jenis tiang bor dengan enlarge base. diperhitungkan daya dukung tiang normal dan daya dukung dengan mengabaikan friksi pada 10 meter dari permukaan karena pada daerah tersebut diasumsikan mengalami likuifaksi. Data yang digunakan hanya berdasarkan DB3.

Tabel 3. Daya dukung ujung tiang dengan mengabaikan friksi

\begin{tabular}{|c|c|c|c|c|c|c|}
\hline Diameter & 1 & \multirow{3}{*}{ ke } & 1.2 & meter & SF & 2.5 \\
\hline Keliling & 3.14 & & 3.768 & meter & & \\
\hline Ap & 0.785 & & 1.1304 & meter & & \\
\hline
\end{tabular}

\begin{tabular}{|c|c|c|c|c|c|c|}
\hline Depth (m) & Jenis Tanah & $\gamma\left(\right.$ ton $\left./ \mathbf{m}^{3}\right)$ & $\gamma^{\prime}\left(\operatorname{ton} / \mathbf{m}^{3}\right)$ & $s_{u}\left(\right.$ ton $\left./ m^{2}\right)$ & $\mathbf{q}_{\mathrm{p}}\left(\operatorname{ton} / \mathrm{m}^{2}\right)$ & $\mathbf{Q}_{\mathrm{p}}$ (ton) \\
\hline 1 & Clayey Silt & 1.63 & 0.63 & 21 & 189 & 148.365 \\
\hline 2 & Clayey Silt & 1.63 & 0.63 & 21 & 189 & 148.365 \\
\hline 3 & Clayey Silt & 1.79 & 0.79 & 21 & 189 & 148.365 \\
\hline 4 & Clayey Silt & 1.79 & 0.79 & 21 & 189 & 148.365 \\
\hline 5 & Clayey Silt & 1.79 & 0.79 & 14 & 126 & 98.91 \\
\hline 6 & Clayey Silt & 1.79 & 0.79 & 14 & 126 & 98.91 \\
\hline 7 & Clayey Silt & 1.69 & 0.69 & 35 & 315 & 247.275 \\
\hline 8 & Clayey Silt & 1.69 & 0.69 & 35 & 315 & 247.275 \\
\hline 9 & Clayey Silt & 1.58 & 0.58 & 21 & 189 & 148.365 \\
\hline 10 & Clayey Silt & 1.58 & 0.58 & 21 & 189 & 148.365 \\
\hline 11 & Silt & 1.58 & 0.58 & 48 & 432 & 339.12 \\
\hline 12 & Silt & 1.58 & 0.58 & 48 & 432 & 339.12 \\
\hline 13 & Silt & 1.58 & 0.58 & 42 & 378 & 296.73 \\
\hline 14 & Silt & 1.58 & 0.58 & 42 & 378 & 296.73 \\
\hline 15 & Silt & 1.45 & 0.45 & 35 & 315 & 247.275 \\
\hline 16 & Silt & 1.73 & 0.45 & 35 & 315 & 247.275 \\
\hline 17 & Clayey Silt & 1.73 & 0.73 & 28 & 252 & 197.82 \\
\hline 18 & Clayey Silt & 1.58 & 0.73 & 28 & 252 & 197.82 \\
\hline 19 & Silt & 1.58 & 0.58 & 28 & 252 & 197.82 \\
\hline 20 & Silt & 1.83 & 0.58 & 28 & 252 & 197.82 \\
\hline 21 & Sand & 1.83 & 0.83 & & 70.3654 & 55.236839 \\
\hline 22 & Sand & 1.83 & 0.83 & & 293.1684 & 230.137194 \\
\hline 23 & Sand & 1.83 & 0.83 & & 293.1684 & 230.137194 \\
\hline 24 & Sand & 1.83 & 0.83 & & 240.3981 & 188.7125085 \\
\hline 25 & Sand & 1.83 & 0.83 & & 240.3981 & 271.7460122 \\
\hline
\end{tabular}


Tabel 4. Daya dukung selimut tiang dan daya dukung total dengan mengabaikan friksi

\begin{tabular}{|c|c|c|c|c|c|c|}
\hline$\alpha$ & As (m2) & $\mathbf{f}_{s}\left(\right.$ ton $\left./ \mathbf{m}^{2}\right)$ & $\mathbf{Q}_{s}$ (ton) & $\mathbf{Q}_{s}$ kumulatif (ton) & $\mathbf{Q}_{\text {ult }}$ (ton) & $\mathbf{Q}_{\text {all }}$ (ton) \\
\hline 0.55 & 3.14 & 11.55 & 72.534 & & 148.365 & 59.346 \\
\hline 0.55 & 3.14 & 11.55 & 72.534 & & 148.365 & 59.346 \\
\hline 0.55 & 3.14 & 7.7 & 48.356 & & 98.91 & 39.564 \\
\hline 0.55 & 3.14 & 19.25 & 120.89 & & 247.275 & 98.91 \\
\hline 0.55 & 3.14 & 11.55 & 72.534 & & 148.365 & 59.346 \\
\hline 0.55 & 3.14 & 26.4 & 165.792 & 165.792 & 504.912 & 201.9648 \\
\hline 0.55 & 3.14 & 23.1 & 145.068 & 310.86 & 607.59 & 243.036 \\
\hline 0.55 & 3.14 & 19.25 & 120.89 & 431.75 & 679.025 & 271.61 \\
\hline 0.55 & 3.14 & 15.4 & 96.712 & 528.462 & 726.282 & 290.5128 \\
\hline 0.55 & 3.14 & 15.4 & 96.712 & 625.174 & 822.994 & 329.1976 \\
\hline & 3.14 & 3 & 9.42 & 634.594 & 689.8308 & 275.9323 \\
\hline & 3.14 & 15 & 47.1 & 681.694 & 911.8312 & 364.7325 \\
\hline & 3.14 & 15 & 47.1 & 728.794 & 958.9312 & 383.5725 \\
\hline & 3.14 & 12 & 37.68 & & 917.5065 & 367.0026 \\
\hline & 3.768 & 12 & 45.216 & & 1000.5400 & 400.2160 \\
\hline
\end{tabular}

\section{Analisis gesekan selimut negatif}

Dalam melakukan analisis gesekan selimut negatif diperhitungkan hingga kedalaman 10 meter dari permukaan karena pada bagian itu diasumsikan mengalami likuifaksi, sehingga dapat terjadi gesekan selimut negatif.

Tabel 5. Analisis gesekan selimut negatif

\begin{tabular}{|c|c|c|c|c|c|c|c|c|}
\hline Lapis & Kedalaman $(\mathbf{m})$ & $\boldsymbol{\gamma}\left(\mathbf{t o n} / \mathbf{m}^{\mathbf{3}}\right)$ & $\boldsymbol{\gamma}^{\prime}\left(\mathbf{t o n} / \mathbf{m}^{\mathbf{3}}\right)$ & $\mathbf{p}$ & $\mathbf{K}^{\prime}$ & $\tan \boldsymbol{\delta}^{\prime}$ & $\mathbf{Q n}$ & Qn Total \\
\hline 1 & 2 & 1.63 & 0.63 & 3.1429 & 0.6093 & 0.2523 & 0.6087 & \\
\hline 2 & 4 & 1.79 & 0.79 & 3.1429 & 0.6093 & 0.2523 & 3.0532 \\
\hline 3 & 2 & 1.69 & 0.69 & 3.1429 & 0.6093 & 0.2523 & 0.6667 & \multirow{2}{*}{4.889} \\
\hline 4 & 2 & 1.58 & 0.58 & 3.1429 & 0.6093 & 0.2523 & 0.5604 & \\
\hline
\end{tabular}

\section{HASIL DAN PEMBAHASAN}

\section{Potensi likuifaksi}

Dari pengujian menggunakan 4 metode di atas, yaitu metode Tsuchida, Chinese Criteria, Bray \& Sancio dan Seed et al, maka didapatkan data analisis potensi likuifaksi yang akan dipaparkan pada Tabel 6.

Tabel 6. Hasil potensi likuifaksi dari 3 titik pengujian

\begin{tabular}{|c|c|c|c|c|}
\hline Titik & Tsuchida & Chinese Criteria & Bray dan Sancio & Seed et al \\
\hline DB1 & Potensi & Tidak Berpotensi & Tidak Berpotensi & Tidak Berpotensi \\
\hline DB2 & Potensi & Tidak Berpotensi & Tidak Berpotensi & Tidak Berpotensi \\
\hline DB3 & Potensi & Tidak Berpotensi & Tidak Berpotensi & Tidak Berpotensi \\
\hline
\end{tabular}

Dari tabel tersebut didapat bahwa sampel tanah berpotensi mengalami likuifaksi dengan metode Tsuchida. Sedangkan dengan 3 metode lainnya, sampel tanah tidak berpotensi mengalami likuifaksi. 


\section{Rasio tengangan siklik (CSR) dan rasio hambatan siklik (CRR)}

Berikut adalah hasil yang didapat dari 3 sampel tanah dengan membandingkan antara $\tau_{\mathrm{av}}$ dan $\tau_{\mathrm{h}}$.

Tabel 7. Perbandingan $\tau_{\mathrm{av}}$ dan $\tau_{\mathrm{h}}$ untuk DB1

\begin{tabular}{|c|c|c|c|}
\hline \multirow{2}{*}{$\begin{array}{c}T_{\text {av }} \\
\left.\text { (ton } / \mathrm{m}^{2}\right)\end{array}$} & \multicolumn{1}{|c|}{$\begin{array}{c}T_{\mathrm{h}} \\
\left.\text { (ton } / \mathrm{m}^{2}\right)\end{array}$} \\
\hline 0.6255 & $>$ & 0.1364 & POTENSI \\
\hline 1.2522 & $>$ & 0.1493 & POTENSI \\
\hline 1.8683 & $>$ & 0.1990 & POTENSI \\
\hline
\end{tabular}

Tabel 8. Perbandingan $\tau_{\mathrm{av}}$ dan $\tau_{\mathrm{h}}$ untuk DB2

\begin{tabular}{|c|c|c|c|}
\hline \multirow{2}{*}{$\begin{array}{c}T_{\text {av }} \\
\text { (ton } / \mathrm{m}^{2} \text { ) }\end{array}$} & & $\begin{array}{c}\mathrm{T}_{\mathrm{h}} \\
\left.\text { (ton } / \mathrm{m}^{2}\right)\end{array}$ & \\
\cline { 1 - 1 } 0.6371 & $>$ & 0.2013 & POTENSI \\
\hline 1.1557 & $>$ & 0.2750 & POTENSI \\
\hline 1.7091 & $>$ & 0.3659 & POTENSI \\
\hline 2.3554 & $>$ & 0.5615 & POTENSI \\
\hline 2.5571 & $>$ & 0.7287 & POTENSI \\
\hline
\end{tabular}

Tabel 9. Perbandingan $\tau_{\mathrm{av}}$ dan $\tau_{\mathrm{h}}$ untuk DB3

\begin{tabular}{|c|c|c|c|}
\hline \multirow{2n}{*}{$\begin{array}{c}T_{\mathrm{av}} \\
\left(\text { ton } / \mathrm{m}^{2}\right)\end{array}$} & $>$ & $\begin{array}{c}\mathrm{T}_{\mathrm{h}} \\
\left(\text { ton } / \mathrm{m}^{2}\right)\end{array}$ & \\
\cline { 1 - 1 } 0.6293 & $>$ & 0.1989 & POTENSI \\
\hline 1.2635 & $>$ & 0.2556 & POTENSI \\
\hline 1.9207 & $>$ & 0.3267 & POTENSI \\
\hline 2.5185 & $>$ & 0.4982 & POTENSI \\
\hline 3.0184 & $>$ & 0.7007 & POTENSI \\
\hline
\end{tabular}

Keterangan: $\tau_{\mathrm{av}}=$ rasio tegangan siklik $(\mathrm{CSR})$

$\tau_{\mathrm{h}}=$ rasio hambatan siklik $(\mathrm{CRR})$

Dari data dari Tabel 7., Tabel 8., maupun Tabel 9., menunjukkan bahwa nilai CSR lebih besar dari nilai CRR, maka dapat disimpulkan bahwa dengan perhitungan CRR dan CRR, sampel tanah ini mengalami likuifaksi.

\section{Daya dukung tiang}

Setelah mendapatkan data bahwa ketiga sampel tanah terindikasi terjadi likuifaksi, maka berpengaruh terhadap friksi pada selimut tiang. Daya dukung selimut tiang 2 meter dari atas dan 2 meter dari bawah tidak memperhitungkan friksi. Selain itu, untuk perhitungan dengan mengabaikan friksi, daya dukung total yang didapat dikurangi dengan perhitungan gesekan selimut negative (NSF). Pada penelitian ini, perhitungan dilakukan dengan menggunakan data deep boring 3 (DB3).

Analisis awal yang dilakukan tidak mengabaikan friksi hingga kedalaman 10 meter (keadaan normal), tetapi hanya mengabaikan friksi akibat pile cap dan enlarge base. Berdasarkan daya dukung tiang normal dari hasil analisis, didapat daya dukung tiang total sebesar 525.9416 ton.

Pada proses analisis daya dukung tiang, friksi diabaikan hingga kedalaman 10 meter. Hal ini dikarenakan adanya potensi likuifaksi yang terjadi pada 3 sampel tanah yang ada. Berdasarkan data dari Tabel 4., daya dukung tiang yang didapat dengan SF 2.5 sebesar 400.216 ton. Untuk perhitungan yang didapat, perlu dikurangi dengan gesekan selimut negatif yang didapat dari analisis data. Sehingga daya dukung tiang total dengan SF 2.5 sebesar 395.327 ton. Apabila menggunakan SF sebesar 2.5, daya dukung yang didapat lebih besar dari data yang diberikan dari perencana. Maka kemungkinan perencana telah mengantisipasi terjadinya likuifaksi pada proyek tersebut.

\section{Gesekan selimut negatif}

Gesekan Selimut Negatif dihitung sampai kedalaman 10 meter karena potensi likuifaksi yang diperkirakan sampai kedalaman 10 meter. Dari hasil perhitungan pada Tabel, didapat besar gesekan selimut negatif yang terjadi sebesar 4.889 ton. 


\section{KESIMPULAN}

Dari hasil analisis menggunakan grafik maupun perhitungan, untuk mendapat potensi likuifaksi, didapati bahwa daerah di sekitar Jakarta khususnya di daerah Depok masih terindikasi mengalami likuifaksi. Hal ini dapat diliihat pada Tabel 6., dan Tabel 7. Apabila data tanah pada proyek menggunakan analisis berdasarkan grafik, didapati hanya grafik Tsuchida yang memenuhi persyaratan potensi likuifaksi. Untuk grafik Chinese Criteria, Bray \& Sancio dan Seed et al, tidak terdapat potensi likuifaksi. Sedangkan apabila menggunakan metode lain, yaitu perhitungan rasio tegangan siklik (CSR) dan rasio hambatan siklik (CRR), dapat disimpulkan bahwa masih sampel tanah yang ada masih berpotensi mengalami likuifaksi. Karena rasio tegangan siklik lebih besar dibandingkan hambatan siklik.

Karena adanya potensi likuifaksi, maka daya dukung tiang yang digunakan tidak memperhitungkan gesekan selimut pada tiang seperti analisis yang terdapat pada Tabel 3. dan Tabel 4. Sehingga, tiang yang pada mulanya memiliki daya dukung total sebesar 525.9416 ton berkurang karena mengabaikan gesekan selimut sedalam 10 meter menjadi 400.2160 ton. Likuifaksi juga menyebabkan terjadinya gesekan selimut negatif yang menyebabkan daya dukung tiang total berkurang. Berdasarkan data yang ada, didapatkan besar gesekan selimut negatif yang terjadi adalah sebesar 4.8889 ton. Maka didapatkan daya dukung tiang total per tiang adalah 395.327 ton.

Maka pada daerah yang pada dasarnya kecil kemungkinan terjadi likuifaksi, sebaiknya dapat menghitung potensi likuifaksi berdasarkan 4 metode di atas atau dengan CSR dan CRR. Tetapi, perlu juga melihat dari berbagai sisi, seperti jenis tanah, kedalaman tiang, dan sebagainya.

Penelitian ini dilakukan dengan melakukan analisis terhadap daya dukung aksial. Maka dapat ditinjau dari sisi lain, yaitu analisis terhadap daya dukung arah lateral, karena dapat berpengaruh kepada tiang.

\section{DAFTAR PUSTAKA}

Blake, T.F. (1997). Formula (4), Summary Report of Proceedings of the NCEER Workshop on Evaluation of Liquefaction Resistance of Soils, Youd,T.L. dan Idriss, I.M., et.,al. Technical Report NCEER, 97-0022.

Bowles, Joseph E. (1982). Foundation Analysis and Design 3rd edition. The McGraw-Hill Companies.

Bray, J. D., Sancio, R. B., Riemer, M. F., dan Durgunoglu, T., Liquefaction susceptibility of fine-grained soils. Proc., 11th Int. Conf. on Soil Dynamics and Earthquake Engineering and 3rd Int. Conf. on Earthquake Geotechnical Engineering, D. Doolin et al., eds., Stallion Press, Singapore, 655-662. 2004.

Briaud, J.L., Tucker, L., and Felio, G.Y. (1983). Pressuremeter, Cone penetrometer and foundation design. Short course notes, vol I, Texas A\&M University, College Station, Texas.

Das, Braja. M. (1983). Principles of Foundation Engineering Seventh Edition. Cengage Learning.

Hanafiah, K.A. (2007). Dasar-dasar Ilmu Tanah. RajaGrafindo Persada, Jakarta.

Hardiyatmo, H.C. (2002). Teknik Pondasi I, Edisi Kedua, Penerbit Beta Offset, Yogyakarta.

Idriss I.M. \& Boulanger R.W. (2010). SPT-Based Liquefaction Triggering Procedures, December 2010.

Marcuson, W.F. (1978). III, Definition of Term Related to Liquefaction. Journal of Geotechnical Engineering (104).

O’Neill, M.W., Brown, D.A., Townsend, F.C., dan Abar, N. (1997) Innovative Load Testing of Deep Foundations, Transportations Research Record 1569, Transportation Research Board, Washington, D.C, pp. 17-25.

Paulus P. Rahadjo. Manual Pondasi Tiang Edisi 5, Universitas katolik Parahyangan-Bandung

Reese, L.C. \& Wright, S.J. (1977). Drilled Shaft Design and Construction Guidelines Manual, Vol.1, U.S Department of Transportation, Washington, D.C.

Seed.,et.al. (1982). Recent advances in soil liquefaction engineering: a unified and consistent framework. Keynote presentation, 26th Annual ASCE Los Angeles Geotechnical Spring Seminar, Long Beach, CA, 2003

Seed, H. Bolton dan Idriss, I.M., Ground Motion and Soil Liquefaction During Earthquake, Earthquake Engineering Research Institute, Berkeley.

SNI 1726-2012, Tata Cara Perencanaan Ketahanan Gempa untuk Struktur Bangunan Gedung dan Non-Gedung.

Sukandarrumidi. (2010). Bencana Alam dan Bencana Anthropogene: Petunjuk Praktis untuk Menyelamatkan. Yogyakarta: Kanisius. Hlm: 43-48.

Tsuchida, H. (1970). Prediction and Countermeasure Against the Liquefaction in Sand Deposits, Abstract of the Seminar in the Port and Harbor Research Institute.

USGS. (2013). About Liquefaction. U.S. Geological Survey.

Youd, T. L. (1984). Geologic Effects-Liquefaction and Associated Ground Failure, pp. 210-232 in Proceedings of the Geologic and Hydrologic Hazards Training Program, Open-File Report 84-760, U.S. Geological Survey, Menlo Park, California.

Youd, T. L dan Idriss, I. M.,et.al (2001). Liquefaction Resistance of Soils: Summary Report from the 1996 NCEER and 1998 NCEER/NSF Workshops on Evaluation of Liquefaction Resistance of Soils, Journal of Geotechnical and Geoenvironmental Engineering, American Society of Civil Engineers. 